\title{
THE PERSPECTIVES OF ACEHNESE ULAMA AND EDUCATION EXPERTS IN SHAPING IAIN LHOKSEUMAWE AS CAMPUS OF CIVILIZATION
}

\author{
Al Husaini M. Daud, Munadi Usman \& Nuraini \\ IAIN Lhokseumawe \\ Jl. Medan-Banda Aceh, Km. 275 Lhokseumawe, Aceh, 24351 \\ e-mail: ahd@iainlhokseumawe.ac.id, munadiusman83@gmail.com, marsnuraini@gmail.com
}

\begin{abstract}
This article discusses about a search of the resources of Islamic Civilization as perceived by Acehnese Islamic scholars and education practitioners in the context of shaping a campus of civilization. This study is a qualitative research applying phenomenology approach. Most data were acquired from informants who are directly related to the theme in question. From the results of the field data, it was found that the main sources of a solid civilization, according to scholars and figures of Aceh education, were the Qur'an and the Sunnah of the Prophet, the plurality of Islamic societies, and the results of external Islamic civilization. The three main sources of Islamic civilization became the initial basis for the development of a civilized campus in its true meaning.
\end{abstract}

Abstrak: Tulisan ini mendiskusikan tentang pencarian sumber-sumber peradaban Islam menurut para ulama dan tokoh pendidikan Aceh dalam membentuk kampus peradaban. Seluruh kajian dalam penelitian ini secara eklektik tergolong ke dalam penelitian kualitatif dengan meng-gunakan pendekatan fenomenologi. Data dalam tulisan ini dikumpulkan melalui wawancara terhadap para informan yang berkaitan langsung dengan tema dimaksud. Dari hasil analisis data ditemukan bahwa sumbersumber utama tegaknya peradaban yang kokoh menurut ulama dan tokoh pendidikan Aceh adalah al-Qur'an dan Sunnah Rasulullah, pluralitas masyarakat Islam, dan hasil peradaban eksternal Islam. Ketiga sumber utama peradaban Islam tersebut menjadi basis awal bagi perkembangan kampus yang berperadaban dalam makna yang sesungguhnya.

Keywords: Islamic civilization sources, ulama, campus of civilization 
Al Husaini M. Daud, et al.: The Perspectives of Acehnese Ulama

\section{Introduction}

The transformation from State Islamic College of Malikussaleh Lhokseumawe to State Islamic Intitute of Lhokseumawe based on presidencial decree number 70 year 2016 is a new stage for the development of Islamic higher school to become more advance and competitive. This the form of a comitment from the effort of status change and the objectives to present a superior campus at a regional and an international level. For this, a preparation and a grand design of a good and latest campus management is needed.

Besides, the branding icon of State Islamic Institute of Lhokseumawe has been introduced since January 2018. At once, this branding Icon was "Seumpuena" (an academic motivation) for the resurrection of a noble civilization in the middle of academic community. This statement was aimed to the change of intelectual atmosphere thoroughly post status diversion from State Islamic College to become State Islamic Institute of Lhokseumawe. Nevertheless, the search for dimension and essence of the intended campus of civilization was continually done with the rhythm of the time flow.

Time changes and industrial reformation occur today require each university to be able to adjust with them. On the one hand, tertiary institutions are formal institutions mandated by the government to produce intellectuals and experts in various fields of education according to the demands of the era and the world of work. On the other hand, every university is in the arena of competition to always compete to be the best and the most favorite choice at the national and international levels. These two sides are fundamental reasons for campus managers, both public and private ones, to create competitive tertiary designs and to be able to bring real change in society through a superior educational process.

The educational essence is not only limited to the tranfer of knowledge but also more importantly to the transfer of value process ${ }^{1}$. Higher education as the agent of change must be able to stand still to give color and peculiarity in creating a madani society in the meaning of the wholeness in thinking, zikr, and acting. The Islamic civilization has a meaning as a struggle in presenting Islam in the space and time of human life history which is the main trusteeship charged by Allah. Hence, Islamic civilization has a fundamental trancedental structure because it was built on the fondation of revelation; where Allah acts as the main director in the process of reconstructing Islamic civilization. The direction is given beautifully in the pages of His word both in the verses in qauliyah verses (the Qur'an and Hadith) and kauniyah (universe) verses.

Humans are the main element in a building of civilization, because he is a perpetrator of civilization. Therefore, any steps taken to manifest a civilization will not be realized if it ignores aspects of education and fostering human existence. Serious and sustainable education and coaching will create superior human resources as characteristics of madani

${ }^{1}$ Paulo Preire, Pendidikan Masyarakat Kota (Yogyakarta: LKiS, 2007), p. 13. 
civilians. A madani human resources reflect the construction of advanced civilizations. Universitality of a civilization describes a good social order, moral based that guarantees a balance between personal rights and obligations with communal rights and obligations. The embodiment of civil society can be in the form of a collection of communities in a broad scope such as a country, but can also be in a narrower scope such as one province, district, village and even one particular work unit, if the community has a madani community spirit and character.

Nurcholis Madjid defines madani society as an egalitarian, participative, fair, open, and democratic society under the society and humanity concepts desired by the concept of good governance. Madani society embodied the advanced society with several advantages in working, and democracy or human rights enforcement. To realize this, concrete and systematic efforts are needed as carried out by the Prophet when he formed the Medina community through laying the foundations of Islamic aqeedah and democracy then slowly building the foundations of society, state, and humanity. Furthermore, a democratic, transparent, civilized society is developed by also having potential, tolerant, aspirative, coordinative, motivating, participable, consistent, simple, synchronous, integral, ethics, moral, emancipation, and human right recognizable capabilities built. ${ }^{2}$

The quality of superior human resources is a product of education and coaching that is carried out selectively and continuously in a long duration. These superior humans will have conceptual and contextual awareness and abilities about how to build Islamic civilization. The task of educating and fostering referred to is the most important responsibility of educational institutions, including universities as one of the pillars of educational institutions. The campus of civilization is an academic institution whose main focus is the birth of human beings who think, have spirit and act great with knowledge, faith, and jihad which is no longer in doubt.

In the present era, higher education is a work unit that has a direct role in realizing a civilized society. But beforehand a university must first improve itself through the guidance of the academic community towards a community that has the characteristics of madani society. The point is that universities in realizing community civilization must first strive to become a civilization campus in terms of human resources and pre-facilities. Higher education as an agent of change for the community needs to review the pattern or concept of madani society that the Prophet (peace and blessings of Allah be upon him) once proposed to the people of Medina. These basic principles and values need to be articulated in the form of software or concepts that might be applied in the organization of a higher education institution. The software is designed in such a way as to consider the latest developments

${ }^{2}$ Nurcholish Madjid, et al., Kehampaan Spiritual Masyarakat Modern: Respon Transformasi Nilai-Nilai Islam Menuju Masyarakat Madani (Jakarta: Mediacita, 2000), p. 318. 
in the field of education management and information technology so that the format is adaptive to the progress of the times.

The preparation of campus civilization software as mentioned above can be done with a phenomenological approach through in-depth observation and interviews with leaders and practitioners in the field of education, scholars and community leaders. The various thoughts that they conveyed are then drawn to the essence and summarized into an operational concept. Educational practitioners, scholars and community leaders are the social elements who understand the essence of higher education and the purpose of its establishment.

To form an independent and superior campus as the basis of the "campus of civilization" a study of a concept is needed in the form of a representative and efficient campus management design, in order to improve the quality of education and produce quality graduates. Based on this reality, the writing from the results of this study aims to explore the thoughts of scholars and educational practitioners in Aceh related to the sources and the chracteristics of good Islamic civilization to shape a superior, competitive, and globally-minded college.

\section{Civilization in the Scientific Study}

Before discussing the thesis of civilization, it is firstly needed to talk about the terminology of civilization. Many questions arise regarding the term "civilization" which is sometimes used interchangeably with the same meaning as the term "culture". E.B. Taylor, for example, equates civilization with culture. Both are understood as "a complex whole that includes knowledge, beliefs, arts, laws, morals, customs, and every ability and habit that humans have as members of society". At least, according to Dawam Rahardjo, there is an overlapping understanding between the two terms so that there is obscurity or there are several different meanings of the same term. ${ }^{3}$

Huntington in Dawam Rahardo notes the notion of civilization by referring to civilized conditions, namely having good character and self-control. The word civilization does come from the word "adab" from Arabic which means manners, distinguishes itself from uncivilized or barbarian behavior. If this is the understanding, then civilization is similar to the understanding of civil society which is now more famous. In the 19th century, this understanding was developed to include growth through the development of science and skills, thus enabling people to become civilized. This reality makes civilization closely related to science and education. ${ }^{4}$

A civilization is born, according to Arnold Toynbee, not rooted in race or geographical

${ }^{3}$ M. Dawam Rahardjo, "Benturan Ataukah Dialog Peradaban," in Sejarah \& Dialog Peradaban (Jakarta: LIPI Press, 2005), p. 1014.

${ }^{4} \mathrm{Ibid}$. 
environment, but depends on two combinations of conditions, namely the existence of a creative minority and an appropriate environment. The environment according to this is not very profitable nor is it very detrimental. The mechanism of birth of a civilization based on these conditions is formulated in the process of interplay of challenges and responses. The environment challenges people and society through their creative minority to respond successfully to the challenge. The solution given by the creative minority was then followed by the majority. This process is called mimesis. New challenges then emerge, followed by successful responses. This process continues. Society is in the process of moving on and certain movements bring it to the level of civilization. ${ }^{5}$

Previously, Ibn Khaldûn, the largest Muslim historian and sociologist in history, revealed in his book "Muqaddimah" that human civilization is something that moves and processes like living things. For him, human life will always experience processes and changes. This is a sunnatullah. ${ }^{6}$ This means that biologically, humans will experience a phase of birth, baby, children, adolescents, adults, old people, and die. The civilization cycle also begins with emergence, growth, development, glory, collapse, and finally destruction. In the sacred text of Islam (the Qur'an) it is explained that the period (glory and collapse) was circulated among humans. This means that biologically, humans will experience a phase of birth, baby, children, adolescents, adults, old, and die. The civilization cycle also begins with emergence, growth, development, glory, collapse, and finally destruction. In the sacred text of Islam (the Qur'an) it is explained that the period (glory and collapse) was circulated among humans. ${ }^{7}$ It may be that Ibn Khaldûn was inspired by this verse, because the verse which discusses the Uhud war, if viewed from the general lafadz, illustrates the clarity of events in the form of falling-up, triumphant, and going back and forth a human civilization.

It may be that Ibn Khaldûn was inspired by this verse, because the verse which discusses the Uhud war, if viewed from the general lafadz, illustrates the clarity of events in the form of falling-up, triumphant - collaps, and back and forth a human civilization. ${ }^{8}$ Perhaps this statement is closer to the meaning of civilization carried by Dîn al-Islâm (Islamic teachings), if it is illustrated in the editorial Raghib without intending to be discriminatory and fanatical, that Islamic civilization is the only civilization in the world that fulfills excellence in forging three components; that is civilization ensuring the intervention of the creator in the formation of a civilization. ${ }^{9}$

${ }^{5}$ Arnaold J. Toynbee, A Study of History (London: Oxford University Press and Thames and Hudson Ltd., 1972), pp. 91-101.

${ }^{6}$ Andil Faisal Bakti, "The Political Thought and Communication of Ibn Khaldun," in The Dinamycs of Islamic Civilization (Yogyakarta: Titian Ilahi Press, 1998), p. 235.

${ }^{7}$ Q.S. Âli ‘Imrân/3: 140.

${ }^{8}$ Raghib As-Sirjani, Sumbangan Peradaban Islam Pada Dunia, tr. Sonif, Masturi Ilham and Malik Supar (Jakarta: Pustaka al-Kautsar, 2017), p. 8.

${ }^{9}$ Ibid., p. 10. 
As-Sirjani further mapped the basics of Islamic civilization sources which contained the Qur'an and Sunnah, Islamic society, and paved the way for other parties. The Qur'an and the Sunnah are prescribing the Ummah for every field of science to the benefit and happiness of human beings perfectly. While the source of Islamic society is the result of mixing the population of the Islamic world which is so diverse. Likewise the world population that has entered the banner of Islam is an important factor in the civilization of well-being. Islamic civilization has opened wide avenues for human civilization and benefited from it. ${ }^{10}$

Other than that the characteristics that must exist in an Islamic civilization consist of universality, monotheism, justice and moderation, and moral. Islamic civilization in principle houses all peoples and nations. It must be universal in its horizons transcends breadth and height, is not bound by geographical climate, is free from all human types, and is not related to historical levels. Furthermore, the superiority of Islamic civilization is that it is stand on the principle of absolute monotheism to Allah SWT, a substance that is not comparable to anything, whether in appearance or power. Humans before Him as servants who are equal in all things. The nature of Wasathan (fair and moderate) is a superior characteristic of Islamic civilization, emphasized on the balance between the body (physical) and spirit (psychic). This tendency of balance is to fulfill the harmonization between human nature and purpose of thought. Likewise, by fulfilling universal harmony in human thought, dreams, desires and intentions. While morals are a limiting fence as well as a basis that is founded on the glory of Islam. ${ }^{11}$

In answering the problem statement, this study will use the Raghib as-Sirjani theory about Islamic civilization. Researchers see the theory in accordance with the researched object, especially which is related to the design of a college supported by the pillars of civilization. The synergy of the sources, characteristics, and pillars of Islamic civilization will create the ideality of civilization in the middle of the intellectual community of the State Islamic Institute of Lhokseumawe in the process of leading madani society.

\section{Perspective as a Theory}

The definition of the actual point of view can be interpreted as a way for someone to judge something that can be explained both verbally and in written. Almost all people always express their perspective or point of view on various things. Based on the types, perspective are classifief in to three, namely (1) the perspective of a bird's eye, namely the way of looking at objects from above, so that in this way it can be easier to describe a space, starting from shape, color, and others; (2) the perspective of the human eye, namely the pendang method by looking at the parallel object, so that it can make it easier to describe

${ }^{10}$ Ibid., pp. 39-51.

${ }^{11}$ Ibid., pp. 52-65 
an actual situation; and (3) the perspective of the worm's eye, namely the way of looking at the object from below, so that this method can produce a dramatic perspective. ${ }^{12}$

Perspective or point of view or which are often analogized as one's perception is a stimulus that is sensed by an individual. It is organized and then interpreted so that the individual can realize and understand what is being sensed. ${ }^{13}$ Miller said that perspective is a conceptual framework; set of assumptions; set of values; and a set of ideas that influence our perceptions and influence our actions in a situation. ${ }^{14}$ The fundamental influence of perspective is to define and direct one's understanding to the communication concepts. Thus the different perspectives used will have different interpretive implications for a reality.

\section{Sources of Civilization in the Perspective of Ulama and Aceh Education Figures}

From the results of research done by researchers in the field by meeting with resource persons, it can be seen that there are at least three main sources of Islamic civilization, namely, the Qur'an and the Sunnah of the Prophet, plurality of Islamic societies, and the results of Islamic external civilization.

\section{Al-Qur'an and Sunnah of the Prophet}

The most basic foundation in laying the building of Islamic civilization is the Qur'an and the sunnah of the Prophet. Both are fundamental principles for the establishment of a civilization that has special characteristics and is different from other civilizations. Privileges and values emitted from these two sources have been proven and enshrined in the gold plate of the history of the journey of human life.

Al-Qur'an is the word of Allah Almighty, which was revealed to the Prophet Muhammad as a miracle, delivered in a mutawatir way from Allah swt itself with the intermediary of the angel Gabriel. Al-Qur'an is the guidance of Islamic society, functions as a compass that ensures the direction of human life. It contains the secrets of Islamic civilization and its majesty, "... which did not come to him (the Qur'an) falsehood both from the front and behind him, which was revealed from the Wise and Most Praised Rabb"15 The Qur'an is

12"Pengertian Perspektif atau Sudut Pandang," in http://www.definisimenurutparaahli. com/pengertian-perspektif-atau-sudut-pandang/accesed on November 24, 2018.

${ }^{13}$ Tony and Barry Buzan, Memahami Peta Pikiran (The Mind Map Book) (Jakarta: Interaksana, 2004), p. 251.

${ }^{14}$ Katherine Miller, Communication Theories: Perspectives. Processes and Contexts (Boston: McGraw-Hill, 2005), p. 36.

${ }^{15}$ Q.S. Fushilat/41: 42. 
the best that humans have from every aspect of life; spirit, mind, society, religion, thought, economy, civilization, military, and also teaching can make people happy. ${ }^{16}$

Tgk H. Nuruzzahri, or more popularly known as Waled Nu revealed in an interview specifically at Ummul Ayman's Dayah that:

The Qur'an must be an integral part of our lives. For example, the blood in our body must be merged with the flesh, so that it is truly human, but if there is meat but has no blood, or vice versa, it is called a fake human. ${ }^{17}$

Accordingly, Tgk. H. Abdul Manan in another term, revealed that there is nothing wrong with revelation and that there is nothing wrong with Islam, we are as a free people, have not been able to reason the substance of the teaching of dien al-Islam using kaffah. ${ }^{18}$ This expression is almost the same as the thesis put forward by Ibn Taimiyyah, as quoted by Tamim Ansary, when responding to the victory of the Mongol army who were able to repel Muslim military forces so that they suffered a very painful defeat throughout world history. In fact, Islamic theologians and Muslim scholars, even Muslims in general, have long been sure that Islamic military success was caused by their never leaving revelation. But when the Islamic military no longer made the word of God an accurate weapon, what happened was a painful losing streak, both from the Mongol forces and from the Crusaders. ${ }^{19}$ Morgan even revealed that the painful event was a big disaster for the Muslim world, and the victory of the Mongols seemed to indicate that God had left Muslims. ${ }^{20}$

In addition to the Qur'an as the main reference for Islamic civilization and must be a guide to the campus activities of Islamic civilization, the Sunnah of the Prophet is the plenary guide to the Book of Allah. If the Qur'an contains the fundamental principles of Islamic teachings including aqeedah, sharia, and akhlak, then the sunnah comes as a viewpoint and the practical application of the sacred text to explain the substance of Islamic teaching to humans. This is confirmed by God in His word;

Allah has given gifts to those who believe when Allah sent among them an Apostle from their own group, who read to them the verses of Allah, cleansed (their souls), and taught them al-Kitab and al-Wisdom and verily before (the coming of the Prophet), they were truly in a real error. ${ }^{21}$

${ }^{16}$ Sirjani, Sumbangan Peradaban, p. 40.

${ }^{17}$ Tgk. Nuruzzahri, Leader of Dayah Ummul Ayman Samalanga, interview in Samalanga, November 142018.

${ }^{18}$ Tgk. H. Abdul Manan, Ketua Majelis Permusyawaratan Ulama (MPU) Aceh Utara, interview in Aceh Utara, November 232018.

${ }^{19}$ Tamim Ansary, Dari Puncak Baghdad: Sejarah Dunia Versi Islam, tr. Yuliani Liputo (Jakarta: Zaman, 2010), p. 267.

${ }^{20}$ David Morgan, The Mongol (Massachusetts: Blackwell Publishing, 2007), pp. 16-18.

${ }^{21}$ Q.S. Âli ‘Imrân/3: 164. 
Al-Qurthubi in al-Jami' li A $\underline{h} k a ̂ m$ al-Qur'ân states that the sunnah is the manhaj nubuwwah which includes his words, deeds, and provisions. ${ }^{22}$

In this case, Abu Manan Blang Jreun in an interview with researchers in his office revealed that the sunnah or hadith of the Prophet is a detailed media for humans for something that is still abstract in the quran.

Higher education institutions should place the Prophet's hadith as the second source after the Qur'an. Because the hadith or sunnah serves as an explanation for us about things that are still unexplained in verse. Not only that, there are verses that are very general in their contents (writer: the substance of the verse), so it needs a more detailed explanation. So no one will be able to explain clearly and clearly as possible except the Messenger of Allah. He knows best about the contents of the Qur'an, because Allah revealed His revelations to the Prophet Muhammad. Then surely he is the one who understands the most and is able to explain the meaning of these general verses to us in detail. Therefore, in my opinion the campus must make the hadith of the Prophet hand in hand with the Qur'an as a foundation in shaping civilization. ${ }^{23}$

From some of the statements above show that the main source in shaping the construction of the campus of civilization is the Qur'an and the Sunnah of the Prophet as a very fundamental foundation.

\section{Plurality of Islamic Communities}

The source of Islamic civilization is not only in the form of teachings from the holy text, namely the Qur'an and hadith as a fundamental principle in the Islamic religion, but other sources also come from the plurality of society. Human unity in truth, goodness, and glory is illustrated at the level of human diversity understanding. God's purpose in creating humans varies in the form of race, ethnicity, and nation is the complement to each other so that His Shari'a looks beautiful in that diversity. It can be seen in the word of God in the text of his qauliyah: "O mankind, verily We created you from a man and a woman and made you nations and tribes so that you would know one another. Surely the noblest person among you on the side of Allah is the one who is the most taqwa among you. Indeed, Allah is All-Knowing". ${ }^{24}$ Relics of civilization and the advantages of different cultures and knowledge from different ethnic groups have led to the formation of superior civilizations.

${ }^{22} \mathrm{Abû}$ 'Abdillâh Muhammad bin Aḥmad al-Anshâry al-Qurthubî, al-Jâmi' li Ahkâm al-Qur'ân (Beirut: Dâr Ihyâ' al-Turâts al-Arabî, 1985), p. 2. For further discussion on this issue, see in general Mhd. Syahnan, "The Image of the Prophet and the Systematization of Ushul al-Fiqh: A Study of al-Shafi'i's Risalah," in Miqot, Vol. 103, 1998; Mhd. Syahnan, Hukum Islam dalam Bingkai Transdisipliner (Medan: Perdana Publishing, 2018).

${ }^{23}$ Tgk. H. Abdul Manan, Cheif of Majelis Permusyawaratan Ulama (MPU) Aceh Utara, Interview in Aceh Utara, November 23, 2018.

${ }^{24}$ Q.S. al- Hujurat/49: 13. 
The results of interviews with Faisal Ali illustrate that the plurality of Islamic societies is a source of Islamic civilization that must be presented inevitably in shaping the framework of Islamic civilization that is more advanced and synergized with human nature. This element cannot be abandoned because its existence greatly determines the majesty of the existence and essence of a civilization;

People think that the source of our civilization depends only on the Qur'an and hadith, but it is not so. Our diversity is also a reference to a civilization. Think about why God created different people, consisting tribes and nations. It's all about getting to know each other. Well ... from the introduction, we will get new knowledge that is not found in us. Mixing our culture with their culture will add to the treasure of a new culture. So are not these cultures will give birth to wealth for that civilization? Because the civilization that I understand is the result of human relations with God, with fellow humans, and the surrounding environment. So if the three threads of these elements get tighter, then certainly the civilization in question will be more radiant and great, of course. ${ }^{25}$

In the study of the classical history of Islamic civilization, as reported by the Raghib As-Sirjani, it was found that Islamic civilization was the result of a mixture of diverse Muslim populations. All people and nations that are under the banner of Islam play an important role as a source of proud power for the formation of a great civilization that has been passed down from generation to generation to perpetuate the treasure of the process on earth. ${ }^{26}$ The civilization was formed from a variety of different origins and forms of population. The population variety is the experts and scholars of the Muslims from the sidelines of the emerging Islamic civilization, their analogy is as marcusuar which spreads the bright light for salik al-haq (truth seeker), and as a node of surviving human thoughts (pen: giving enlightenment to mankind). ${ }^{27}$

This reality cannot be denied that the plurality of Muslims, both seen from the aspects of biological origin, creative thinking, regional origins, to the works produced, all become the source of a great civilization that illuminates the world without dividing the unity of the people. Civilizations that never castigated Arabic and mawali, natives and foreigners, aristocrats and commoners, masters and slaves, and high and low social strata. The integration of all elements and elements of society precisely becomes a magnet for the empowerment of righteous civilizations.

${ }^{25} \mathrm{Tgk}$ H. Faisal Ali, vice chief of Majelis Permusyawaratan Ulama (MPU) Aceh Province, Interview in Banda Aceh, November 172018.

${ }^{26}$ Sirjani, Sumbangan Peradaban Islam, p. 47.

${ }^{27}$ Musthâfâ al-Sibâ’i, Min Rawâ’i Hadhratinâ (Kairo: Dâr al-Waraq wa Dâr al-Salâm, 1998), pp. 36-37. 


\section{Results of Islamic External Civilization}

In the course of the spread of teachings and Islamic Shari'a, Muslim fighters certainly had a lot of contact with the local culture where the missionary location was located. The indigenous people who were the target of the Islamic treatise were of course already possessing their respective civilizations, which sometimes exceeded those of the da'i of Muslims. Therefore, Muslims do not necessarily discredit the local civilization and force them to accept Islamic culture, but on the contrary, make what is in them (the missionary target) as a new source of strength for the height of Islamic civilization. Let's look at some historical fragments, showing that Muslims learn a lot from other nations who have been more advanced in science and technology. One example is when Khalid bin Yazid al-Umawy took and quoted medicine and medicine as well as chemical compounds (equations) from the Greeks into Arabic, then developed it into a science that is very beneficial to the Muslim world. In an interesting story the Messenger of Allah, advocating for Saad bin Abi Waqqash who was suffering from a heart disease to seek treatment from Harith bin Kaladah ast-Tsaqafi, a polytheist physician. The Apostle does not feel inferior or despicable, because medicine is the realm of science, the inheritance of all humans. This shows that the treasury of knowledge obtained outside of Islamic teachings, as long as it does not touch the realm of aqidah/tauhid and damage the morals of the ummah, is also a source of Islamic civilization. The Chairperson of the Langsa City Consultative Assembly's statement in an exclusive interview with the researcher indicated that, in fact, the progress of Islamic civilization in history was also determined by the extent to which Muslims could accept elements outside Islam that supported the development of Islamic culture and civilization. The association of Muslims with the non-Muslim community shaped the inter-cultural synergy which in turn became an advanced Islamic civilization.

... let's see in history, the touch of foreign culture with Islam, actually educates Muslims in everything. In areas conquered by Islam, the local population (which had been conquered) was asked to teach Muslim troops who were still illiterate. There are no Muslim forces who destroy valuable buildings inherited from the local community. On the contrary, these artifacts are saved and studied by Muslim intellectuals and take advantage of them. Incredible Muslims of the past, they are without reluctance and inferior feeling (insulted) making elements of outside culture (infidel) as a source of civilization. But all of that in terms of muamalah, not in the matter of aqidah. When it comes to Aqidah, then lakum dînukum waliyadin (your religion is for you, mine is for me) ${ }^{28}$

Abu Mudi in a special interview with researchers at the Grand Aceh hotel described the beginning of the emergence of the intention of establishing a college in the location of his assisted dayah, even though not a few Islamic scholars at that time were cynical 15, 2018.

${ }^{28} \mathrm{Tgk}$. Zulkarnaen, Chief of Majelis Permusyawaratan Ulama (MPU) Langsa city, November 
about the idea of Abu Mudi. After the return from abroad on a scientific visit of Islamic scholars to several Islamic education institutions in the world-where Abu Mudi became one of the clerics in the group-he found himself very small in the middle of the world's great scholars even with his own students when he could not revealed something he knew, even though it was only a matter of language (colloquial Arabic). This experience led Abu Mudi to feel that he had to innovate in his dayah by establishing a university even though he had to face painful scorn from some of his intellectual colleagues.

The short story above illustrates that the source of a civilization can be obtained from outside parties or a touch of experience gained from association to outside of the community. This small fragment, epistemologically represents external elements (including the element outside Islam) that influence Islamic civilization on a larger scale. More than that, in several notes on the history of the Islamic world, it revealed the glory of Islam in the classical era in various fields, especially science, technology, and the military. All these facts started from expansion to various regions both in the East and West by always prioritizing human values. The mixing of Muslim forces with conquered inhabitants resulted in cultural acculturation and enlightenment of civilization. Not a few nations are embraced by Muslim forces, absorbing Islamic civilization and the results of Islamic culture so that they become developed nations like today.

\section{Conclusion}

Islamic civilization whose the traces are still recorded in history books that the main sources of a solid civilization are the Qur'an and the Sunnah of the Prophet. Privileges and values emitted from these two sources have been proven to be able to strengthen the pillars of advanced civilization and enshrined in the gold plate of the history of human life's journey. In addition, another source as the foundation of Islamic civilization is the plurality of Islamic society. Human unity in truth, goodness, and glory in the construction of Islamic civilization is reflected in the level of understanding of human diversity. Then, other sources of Islamic civilization are the result of an external civilization. In each conquered region, Muslims have never discredited local civilization or forced them to accept Islamic culture, but on the contrary, they made the civilization value in the missionary target as a new source of strength for the height of Islamic civilization. The three main sources of Islamic civilization are the initial basis for the development of a civilized campus in its true meaning.

The characteritics of Civilized Campus of IAIN Lhokseumawe accordings to the Islamic and Acehness Scholars and practitioners covers universality, aqeeda/tauheed tawazun, wasathan (just and moderate) and morality. The advantages of campus of civilization with all of its privilages must stand on the universality charaster and on the foundation of tauheed which is straight and true. It also must be accompanied by tawazun/wasathan 
which means balance, justice, and moderation. It also takes honor morality as the barometer of success. These four characteristics show that Islamic civilization which manifested in the campus environment is a great civilization which has a large and conprehensive scope and in accordance with human nature.

\section{References}

Ansary, Tamim. Dari Puncak Baghdad: Sejarah Dunia Versi Islam, tr. Yuliani Liputo. Jakarta: Zaman, 2010.

Bakti, Andi Faisal. "The Political Thought and Communication of Ibn Khaldun," in The Dinamycs of Islamic Civilization. Yogyakarta: Titian Ilahi Press, 1998.

Buzan, Tony and Barry Buzan. Memahami Peta Pikiran (The Mind Map Book). Jakarta: Interaksana, 2004.

Madjid, Nurcholish, et al. Kehampaan Spiritual Masyarakat Modern: Respon Transpormasi Nilai-Nilai Islam Menuju Masyarakat Madani. Jakarta: Mediacita, 2000.

Miller, Katherine. Communication Theories: Perspectives. Processes and Contexts. Boston: McGraw-Hill, 2005.

Morgan, David. The Mongol. Massachusetts: Blackwell Publishing, 2007.

"Pengertian Perspektif atau Sudut Pandang," in http://www.definisimenurutparaahli. com/pengertian-perspektif-atau-sudut-pandang/, accessed on November 24, 2018.

Preire, Paulo. Pendidikan Masyarakat Kota. Yogyakarta: LKiS, 2007.

Al-Qurthubî, Abû 'Abdillâh Muhamamad bin Aḥmad al-Anshâry. al-Jâmi' li Ahhkâm alQur'ân. Beirut: Dâr Ihyâ' al-Turâts al-'Arabî, 1985.

Rahardjo, M. Dawam. "Benturan Ataukah Dialog Peradaban," in Sejarah \& Dialog Peradaban. Jakarta: LIPI Press, 2005.

As-Sirjani, Raghib. Sumbangan Peradaban Islam Pada Dunia, tr. Masturi Ilham Sonif and Malik Supar, Jakarta: Pustaka al-Kautsar, 2017.

Al-Sibâ'i, Musthâfâ. Min Rawầi Hadhratinâ. Kairo: Dâr al-Waraq wa Dâr As-Salâm, 1998.

Syahnan, Mhd. "The Image of the Prophet and the Systematization of Ushul al-Fiqh: A Study of al-Shafi'i's Risalah," in Miqot, Vol. 103, 1998.

Syahnan, Mhd. Hukum Islam Dalam Bingkai Transdisipliner. Medan: Perdana Publishing, 2018.

Toynbee, Arnold J. A Study of History. London: Oxford University Press and Thames and Hudson Ltd, 1972.

\section{Interviewees:}

Tgk H. Faisal Ali, vice chief of Majelis Permusyawaratan Ulama (MPU) Aceh Province, interview in Banda Aceh, November 17, 2018. 
Tgk. H. Abdul Manan, Cheif of Majelis Permusyawaratan Ulama (MPU) Aceh Utara, interview in Aceh Utara, November 23, 2018.

Tgk. Nuruzzahri, Leader of Dayah Ummul Ayman Samalanga, interview in Samalanga, November 14, 2018.

Tgk. Zulkarnaen, Chief of Majelis Permusyawaratan Ulama (MPU) Langsa City, interview in Langsa, November 15, 2018. 